\title{
PENGARUH COOPERATIVE MEANINGFUL INSTRUCTIONAL DESIGN (C-MID) TERHADAP HASIL BELAJAR SISWA DI MTsN LANGSA
}

\author{
Rosita \\ Alumni Pendidikan Matematika IAIN Langsa \\ Email: rosita@gmail.com
}

\begin{abstract}
ABSTRAK
Model pembelajaran Meaningful Instructional Design (MID) adalah pembelajaran yang mengutamakan kebermaknaan belajar dan efektifivitas dengan cara membuat kerangka kerjaaktivitas secara konseptual kognitif-konstruktivis. Salah satu keunggulan model ini adalah adanya struktur yang jelas dan memungkinkan siswa untuk berbagi dengan pasangan yang berbeda dengan singkat dan teratur, selain itu siswa juga bisa bekerja dengan sesama siswa dalam suasana gotong royong dan memiliki banyak kesempatan untuk mengolah informasi dan meningkatkan keterampilan berkomunikasiAdapun yang menjadi tujuan dalam penelitian ini adalah untuk mengetahui pengaruh yang signifikan dari Model Pembelajaran Cooperatif Meaningful Instructional Design (C-MID) Terhadap hasil belajar siswa di MTsN Langsa. Dalam penelitian ini peneliti menggunakan pendekatan penelitian kuantitatif dengan metode eksperimen. Penelitian ini menggunakan rancangan penelitian Desain Randomized Control Group Pretest-posttest dengan menggunakan pembagian dua kelompok penelitian yaitu kelompok penelitian eksperimen dengan menggunakan pembelajaran Cooperative Meaning Instructional Design (C -MID) dan kelompok penelitian kontrol tanpa menggunakan pembelajaran Cooperative Meaning Instructional Design (C-MID ). sampel pada penelitian ini dengan menggunakan teknik undian yaitu dengan membuat gulungan kertas yang berisi semua populasi dari semua kelas VII, kemudian diambil dua gulungan kertas, gulungan kertas yang pertama sebagai kelas eksperimen yaitu kelas VII.5 dan gulungan kertas kedua sebagai kelas kontrol yaitu kelas VII.6. Instrumen yang digunakan adalah tes yang berbentuk uraian dengan jumlah 5 butir soal. Berdasarkan hasil hipotesis diperoleh $t_{\text {hitung }}=2,36$ dan $t_{\text {tabel }}=1,67$, dan ini berarti $\mathrm{t}_{\text {hitung }} \geq \mathrm{t}_{\text {tabel }}$; sehingga dapat disimpulkan bahwa Ho ditolak dan Ha diterima; yaitu ada Pengaruh Cooperatif Meaningful Instructional Design (C-MID) Terhadap hasil belajar siswa di MTsN Langsa
\end{abstract}

Kata Kunci: Meaningful Instructional Design (MID), Hasil Belajar

\section{PENDAHULUAN}

Pembelajaran matematika di sekolah juga terus berkembang dari waktu ke waktu dengan harapan pembelajaran matematika masa kini dapat mengembangkan bakat dan kemampuan siswa dengan lebih optimal. Selain itu diharapkan agar dengan mempelajari matematika siswa 
dapat dengan mudah memecahkan masalah dalam kehidupan sehari-hari, maka dari itu mata pelajaran matematika perlu diberikan kepada siswa dengan kemampuan bersifat logis analitis, sistematis kritis dan kreatif dalam pemecahan masalah dalam mata pelajaran matematika. Matematika juga merupakan pelajaran yang diajarkan di sekolah dengan frekuensi jam pelajaran yang lebih banyak dibandingkan dengan mata pelajaran lainnya dikarenakan matematika salah satu pelajaran yang dianggap sulit oleh seluruh siswa.

Masalah utama dalam pembelajaran matematika yang dianggap sulit tersebut sekarang ini adalah masih rendahnya daya serap siswa. Hlm ini di buktikan dengan hasil belajar siswa yang senantiasa masih sangat memprihatinkan. Hasil belajar ini tentunya merupakan hasil kondisi pembelajaran yang masih bersifat konvensional yaitu suatu pembelajaran dimana seorang guru mengajar dengan cara mencatat dari buku saja, hanya menggunakan metode ceramah untuk menyampaikan sebuah materi yang sudah dijabarkan dalam buku hingga membuat siswa merasa bosan,jenuh dan mengantuksehingga belum menyentuh aspek kognitif, afektif dan psikomotorik siswa itu sendiri, yaitu bagaimana sebenarnya belajar.

Keberhasilan proses belajar mengajar dapat diukur dari keberhasilan siswa yang mengikuti kegiatan pembelajaran. Keberhasilan tersebut dapat dilihat dari tingkat pemahaman materi dan prestasi belajar siswa. Semakin tinggi pemahaman materi dan prestasi belajar, maka semakin tinggi pula tingkat keberhasilan pembelajaran. Pembelajaran yang pasif akan menghambat kreatifitas pola pikir siswa dalam memahami suatu konsep. Oleh karena itu dalam proses pembelajaran matematika siswa dituntut benar-benar aktif, sehingga daya ingat siswa tentang apa yang telah dipelajari akan lebih baik. Suatu konsep akan lebih mudah dipahami dan diingat oleh siswa bila konsep tersebut disajikan melalui prosedur dan langkah-langkah yang tepat, jelas dan menarik. Permasalahan lain pembelajaran matematika yang ditemukan adalah faktor guru dan materi ajar. Mengingat pentingnya belajar matematika, seorang guru matematika dituntut untuk memahami dan mengembangkan suatu metode pengajaran di dalam kelas untuk mencapai suatu tujuan pembelajaran. Hlm ini juga bertujuan agar dapat mengurangi rasa jenuh pada siswa dan juga rasa takut.

Namun pada kenyataannya proses belajar mengajar yang diterapkan oleh guru itu dalam model pembelajaran yang digunakan tidak sesuai dengan keinginan siswa yang berhubungan langsung pada pembelajaran khususnya pelajaran matematika, ketidaksesuaian model pembelajaran itu karena kurang efektif dan efisien dalam penyampaiannya sehingga menyebabkan tidak seimbangnya kemampuan kognitif, afektif dan psikomotorik, misalnya pembelajaran yang menoton dari waktu ke waktu sehingga siswa merasa bosan sehingga siswa cenderung pasif dan kurang dilibatkan dalam pembelajaran di kelas. Ketidaktepatan penggunaan model pembelajaran tersebut dapat menghambat dan mempengaruhi rendahnya hasil belajar siswa, terlihat pada observasi awal terhadap guru matematika yang mengajar di kelas VII MTsN Kota Langsa. Beliau memberikan hasil nilai ulangan matematika khususnya pada materi segitiga yang diambil pada saat ulangan semester genap tahun 2017.

Nilai ulangan matematika khususnya pada materi segitiga hanya satu kelas yang tuntas dengan rata-ratanya 75 yaitu kelas VII.1 sedangkan kelas yang lainya tidak tuntas hlm ini 
tergolong dalam katagori rendah. Tidak tuntasnya nilai rata-rata siswa pada materi segitiga dikarenakan siswa kurang memahami maksud tujuan dari permasalahan gambar segitiga, siswa kurang paham akan jenis-jenis segitiga, unsur-unsur pada segitiga sehinga siswa tidak mengetahui bagaimana cara menyelesaikan permasalahan yang diberikan. Selain itu cakupan materi segitiga yang luas dan beban materi pelajaran yang cukup banyak tetapi jam pelajaran matematika yang tersedia terbatas dan guru juga belum menemukan model pembelajaran yang yang tepat untuk materi segitiga, hlm inilah yang mengakibatkan rendahnya hasil belajar siswa di MTsN Langsa .

Hasil belajar tes Programme for International Student Assessment (PISA) pada tahun 2012 Indonesia juga menyatakan kemampuan siswa matematik pada saat ini masih rendah. Hlm ini dapat dilihat dari, pencapaian hasil belajar mendapat nilai rata-rata 375 . Indonesia berada diurutan 2 terbawah setelah Peru. Kemampuan matematik siswa Indonesia dibawah level 2 sebesar 75,6\%. Sedangkan kemampuan matematik siswa Indonesia yang mencapai level 5 atau 6 sebesar $0,7 \%$. Hlm ini menunjukkan bahwa hasil belajar siswa masih dibawah nilai rata-rata yang telah ditetapkan oleh PISA. ${ }^{1}$

Pengantisipasian yang dilakukan untuk masalah di atas khususnya pada MTsn Langsa, maka perlu dicarikan formula pembelajaran yang tepat, sehingga dapat meningkatkan hasil siswa dalam pembelajaran matematika. Para guru terus berusaha menyusun dan menerapkan berbagai metode pembelajaran yang bervariasi agar siswa tertarik dan lebih aktif dalam belajar matematika. Melihat permasalahan tersebut, maka diperlukan perbaikan model pembelajaran untuk meningkatkan hasil belajar di MTsn Kota Langsa

Salah satu alternatifnya adalah menerapkan model pembelajaran Meaningful Instructional Design (MID) . Model pembelajaran Meaningful Instructional Design (MID) adalah pembelajaran yang mengutamakan kebermaknaan belajar dan efektifivitas dengan cara membuat kerangka kerja-aktivitas secara konseptual kognitif-konstruktivis .2 Salah satu keunggulan model ini adalah adanya struktur yang jelas dan memungkinkan siswa untuk berbagi dengan pasangan yang berbeda dengan singkat dan teratur, selain itu siswa juga bisa bekerja dengan sesama siswa dalam suasana gotong royong dan memiliki banyak kesempatan untuk mengolah informasi dan meningkatkan keterampilan berkomunikasi. ${ }^{3}$

Model pembelajaran Meaningful Instructional Design (MID) dirasa cocok diterapkan untuk mempelajari matematika pada materi segitiga, karena mereka dapat membagi informasi tentang materi segitiga kepada siswa agar mereta lebih kreatif dalam menggali pemahaman matematika dan lebih membuat mereka kreatif dalam kegiatan belajar mengajar matematika. Model pembelajaran Meaningful Instructional Design (MID) adanya struktur yang jelas dan memungkinkan siswa untuk berbagi dengan pasangan yang berbeda dengan singkat dan teratur,

\footnotetext{
${ }^{1}$ The Third International Mathematics and Science Study (TIMSS).2008. PISA

${ }^{2}$ Evalina \& Hartini. Teori Belajar dan Pembelajaran. (Bogor : Ghlmia Indonesia, 2010), hlm 40

3 Anita Lie, Cooperative Learning, Mempraktekkan Cooperative Learning di Ruang-Ruang Kelas, (Jakarta: Grasindo Gramedia Widiasarana Indonesia, 2004), hlm. 65
} 
selain itu siswa juga bisa bekerja dengan sesama siswa dalam suasana gotong royong dan memiliki banyak kesempatan untuk mengolah informasi dan meningkatkan hasil belajar.

Menurut penelitian Desak Made Agung Ratih Rosmila sari yang penelitiannya berjudul pengaruh penerapan model pembelajaran MID berbantuan Media teka teki silang dan motivasi berprestasi terhadap hasil belajar IPS siswa kelas V SD Gugus Untung Surapati Denpasar Timur yang menyatakan terdapat pengaruh yang signifikan hasil belajar dengan besar hipotesisnya 4 , 37. ${ }^{4}$ Didukung dengan penelitian yang dilakukan sebelumnya seperti penelitian yang dilakukan oleh Husna, yang peneliti lakukan pada MTs Banda Aceh didapatkan informasi bahwa pembelajaran matematika dengan model pembelajaran MID yang dilakukan di sekolah tersebut dapat mengembangkan kemampuan tingkat tinggi matematis siswa sehingga dapat meningkatkan hasil belajar sebesar $65 \%$ dari persentase sebelunya sebelum diterapkan model pembelajaran MID". 5

Perbedaan penelitian sebelumnya peneliti yang hanya melihat hasil belajar dengan menerapkan model MID dengan bantuan alat peraga segitiga pada LKS ( Lembar Kerja Siswa) dalam menentuka luas daerah segitiga, sehingga dari penelitian sebelumnya dapat dijadikan referensi dalam penelitian yang lebih baik. Berdasarkan uraian diatas, maka dipandang perlu untuk melakukan suatu penelitian yang berjudul " Pengaruh Cooperatif Meaningful Instructional Design (C-MID) Terhadap hasil belajar siswa di MTsN Langsa”.

\section{Rumusan Masalah}

Untuk mengarahkan penelitian ini agar terfokus pada penyelesaian masalah, maka penulis merumuskan permasalahan dalam penelitian ini, yaitu apakah terdapat Pengaruh Cooperatif Meaningful Instructional Design (C-MID) Terhadap hasil belajar siswa di MTsN Langsa?

\section{Tujuan Penelitian}

Adapun yang menjadi tujuan dalam penelitian ini adalah untuk mengetahui pengaruh yang signifikan dari Model Pembelajaran Cooperatif Meaningful Instructional Design (C- MID) Terhadap hasil belajar siswa di MTsN Langsa.

\section{Manfaat Penelitian}

Dengan diadakan penelitian tentunya dapat diperoleh hasil, penelitian ini dapat bermanfaat sebagai berikut:

1. Bagi Siswa, dapat membantu siswa dalam menyelesaikan pada materi Himpunan sehingga dapat meningkatkan pemahaman matematik siswa.

\footnotetext{
${ }^{4}$ Made, Desak. Ada pengaruh penerapan model pembelajaran MID berbantuan Media teka teki silang dan motivasi berprestasi terhadap hasil belajar IPS siswa kelas V SD Gugus Untung Surapati (Denpasar Timur.2014. Jurnal Vol 2 No: 1 tahun 2014)

5 Husna.. Peningkatan hasil belajar Matematis Siswa Sekolah Menengah Pertama Melalui Model Pembelajaram Kooperatif ( Banda Aceh .2013. 2013.Jurnal Vol 1 No 2 Tahun 2014)
} 
2. Bagi Guru, sebagai masukan dalam menciptakan pembelajaran yang efektif bagi siswa sehingga dapat meningkatkan prestasi belajar siswa serta menciptakan suasana kelas yang interaktif dalam pembelajaran matematika.

3. Bagi Penulis, sebagai pengalaman yang nantinya akan menjadi bekal dalam melaksanakan kegiatan belajar mengajar dikemudian hari.

4. Bagi Sekolah, sebagai bahan masukan agar dapat lebih kompeten dalam rangka meningkatkan mutu pendidikan.

\section{Pembatasan Masalah}

Agar penelitian ini lebih terarah dan mendapatkan hasil sesuai dengan yang diharapkan, maka perlu dilakukan pembatasan masalah pada materi Segitiga dengan menggunakan Model Pembelajaran Cooperative Meaningful Instructional Design (C-MID) dengan berbantuan alat peraga segitiga untuk menentukan luas daerah pada segitiga Terhadap hasil belajar siswa di kelas VII MTsN Langsa.

\section{Definisi Operasional}

Untuk menghindari penafsiran yang berbeda terhadap istilah yang digunakan dalam penelitian ini, diberikan batasan masalah seperti yang tersebut berikut ini :

\section{Model Pembelajaran}

Model pembelajaran adalah suatu kegiatan perencanaan atau suatu pola yang digunakan sebagai pedoman dalam merencanakan pembelajaran di kelas atau pembelajaran dalam tutorial dan untuk menentukan perangkat-perangkat pembelajaran termasuk di dalamnya buku-buku, film, komputer, kurikulum, dan lain-lain.

\section{Pembelajaran Cooperatif}

Pembelajaran kooperatif merupakan bentuk pembelajaran dengan cara siswa belajar dan bekerja dalam kelompok-kelompok kecil secara kolaboratif yang anggotanya terdiri dari empat sampai enam orang dengan struktur kelompok yang bersifat heterogen.

3. Model Pembelajaran Meaningful Instructional Design (MID)

Model pembelajaran Meaningful Instructional Design (MID) adalah model pembelajaran dengan cara membuat kerangka kerja-aktivitas secara konseptual kognitif-konstruktivis . Salah satu keunggulan model ini adalah adanya struktur yang jelas dan memungkinkan siswa untuk berbagi dengan pasangan yang berbeda dengan singkat dan teratur, selain itu siswa juga bisa bekerja dengan sesama siswa dalam suasana gotong royong dan memiliki banyak kesempatan untuk mengolah informasi dan meningkatkan hasil belajar

4. Model Pembelajan Cooperative ingful Instructional Design ( C-MID) 
Model Pembelajan Cooperative ingful Instructional Design (C-MID) adalah model pembelajaran yang dilakukan secara pembagian kelompok ddengan cara membuat kerangka kerja-aktivitas secara bersama untuk meningkatkan dan mengembangkan kemampuan kognitif .

\section{Hasil Belajar}

Hasil Belajar adalah hasil usaha bekerja atau belajar yang menunjukkan ukuran kecakapan yang dicapai dalam bentuk nilai. Hasil Belajar merupakan hasil yang telah dicapai seseorang dalam melakukan kegiatan dari berbagai aspek dalam proses belajar baik dari segi afektif, kognitif maupun psikomotorik.

\section{KAJIAN TEORI}

\section{A. Model Pembelajaran Kooperatif}

\section{Pengertian Model Pembelajaran Kooperatif}

Menurut Robert E. Slavin sebagaimana yang dikutip oleh Isjoni, pembelajaran kooperatif (cooperative learning) adalah bentuk pembelajaran dengan cara siswa belajar dan bekerja dalam kelompok-kelompok kecil yang anggotanya empat sampai enam orang secara kolaboratif dengan struktur kelompok heterogen. ${ }^{6}$ Pembelajaran kooperatif juga memanfaatkan kelompok dalam pembelajaran yang memungkinkan siswa bekerja bersama untuk memaksimalkan belajar dalam kelompok-kelompok waktu menerima pelajaran atau mengerjakan soal-soal dan tugas-tugas".

Pembelajaran kooperatif dikembangkan dari teori belajar kontruktivisme sosial Vygotsky yang menekankan bahwa pengetahuan di bangun dan dikonstruksi secara mutual. Keterlibatan dengan orang lain membuka kesempatan bagi mereka mengevaluasi dan memperbaiki pemahaman. ${ }^{7}$ Maka dari itu Pembelajaran kooperatif mendukung peserta didik akan lebih mudah menemukan dan memahami konsep yang sulit jika mereka saling diskusi dengan temannya untuk secara rutin bekerja dalam kelompok untuk saling membantu memecahkan masalah-masalah yang kompleks. Jadi hakikat sosial dan penggunaan kelompok sejawat menjadi aspek utama dalam pembelajaran kooperatif. ${ }^{8}$

Model pembelajaran kooperatif ini, guru lebih berperan sebagai fasilitator yang berfungsi sebagai jembatan penghubung ke arah pemahaman yang lebih tinggi, dengan catatan peserta didik sendiri. Guru tidak hanya memberikan pengetahuan pada peserta didik, tetapi juga harus membangun pengetahuan dalam pikirannya. peserta didik mempunyai kesempatan untuk mendapatkan pengalaman langsung dalam menerapkan ide-ide mereka. ${ }^{9}$

Berdasarkan beberapa pengertian tentang model pembelajaran kooperatif dapat disimpulkan bahwa dengan adanya penggunaan model pembelajaran maka upaya untuk menciptakan kondisi belajar bagi peserta didik yang lebig efektif di dalam proses pembelajaran,

${ }^{6}$ Isjoni, Pembelajaran Kooperatif: Meningkatkan Kecerdasan Komunikasi Antar Peserta Didik, (Yogyakarta: Pustaka Pelajar, 2009) hlm. 15.

${ }^{7}$ Agus Suprijono, Cooperative Learning, hlm. 55.

${ }^{8}$ Trianto, Model-Model Pembelajaran, hlm. 41.

9 Rusman, Model-Model Pembelajaran:Mengembangkan Profesionalisme Guru, (Jakarta: PT Raja Grafindo Persada, 2001), hlm. 201. 
yang kegiatannya dirancang melibatkan proses mental dan fisik melalui interaksi antar peserta didik, peserta didik dengan guru, lingkungan, dan sumber belajar lainnya dalam rangka pencapaian kompetensi dasar akan lebih terarah.

Menurut Priyanto dalam bukunya Made Wena, ${ }^{10}$ pembelajaran kooperatif merupakan salah satu model pembelajaran kelompok yang memiliki aturan-aturan tertentu. Prinsip dasar pembelajaran kooperatif adalah siswa membentuk kelompok kecil dan saling mengajar sesamanya untuk mencapai tujuan bersama. Dalam pembelajaran kooperatif siswa pandai mengajar siswa yang kurang pandai tanpa merasa dirugikan. Siswa kurang pandai dapat belajar dalam suasana yang menyenangkan karena banyak teman yang membantu dan memotivasinya. Siswa yang sebelumnya terbiasa bersikap pasif setelah menggunakan pembelajaran kooperatif akan terpaksa berpartisipasi secara aktif agar bisa diterima oleh anggota kelompoknya.

Pembelajran kooperatif menurut Herman Suherman mengemukakan bahwa suatu pendekatan yang menekankan kerja sama dalam kelompok. ${ }^{11}$ Maka dari itu Pembelajaran kooperatif tidak sama dengan sekedar belajar dalam kelompok. ada unsur dasar pembelajaran kooperatif yang membedakan dengan pembelajaran kelompok yang dilakukan asal-asalan. Pelaksanaan prinsip dasar pokok sistem pembelajaran kooperatif dengan benar akan memungkinkan guru mengelola kelas dengan lebih efektif yang mampu membantu para siswa untuk meningkatkan sikap positif siswa dalam matematika, dalam pembelajaran kooperatif proses pembelajaran tidak harus belajar dari guru kepada siswa namun dapat belajar bersama teman yang dipandu oleh guru untuk memahmai konsep dari suatu masalah matematika yang telah diberikan.

Slavin dalam Rusman juga berpendapat bahwa pembelajaran kooperatif menggalakkan siswa berinteraksi secara aktif dan positif dalam kelompok. ini membolehkan pertukaran ide dan pemeriksaan ide sendiri dalam suasana yang tidak terancam. ${ }^{12}$ Pertukaran ide dan pemeriksaan ide selalu dibimbing oleh guru yang bertugas sebagai fasilitator dalam proses pembelajaran yang mendukung konsep dalam memahami matematika. Menurut pandangan Piaget dan Vigotsky dalam buku Dimyanti mengemukakan adanya hakikat dari sebuah proses belajar tentang penggunaan kelompok belajar dengan kemampuan anggotanya yang beragam, sehingga terjadi perubahan konseptual. ${ }^{13}$ Dengan demiakian dapat dsimpulkan bahwa pembelajaran kooperatif memberikan kesempatan kepada siswa secara aktif dan kesempatan untuk mengungkapkan sesuatu yang dipikirkan siswa kepada teman akan membantunya untuk melihat sesuatu dengan lebih jelas bahkan melihat ketidaksesuaian pandangan mereka sendiri. Pembelajaran kooperatif dapat dijelaskan dalam beberapa perspektif, yaitu:Perspektif motifasi, artinya penghargaan yang diberikan kepada kelompok yang dalam kegiatannya saling membantu untuk memperjuangkan keberhasilan kelompok.Perspektif sosial, artinya melalui kooperatif setiap siswa akan saling

\footnotetext{
${ }^{10}$ Made Wena, Strategi Pembelajaran Inovatif Kontemporer, (Jakarta: Bumi aksara, 2009), hlm. 189.

${ }^{11}$ Suherman, Erman.. Strategi pembelajaran Matematika Kontemporer.(bandung:Jica.2003)

12 Rusman, Model-Model Pembelajaran... hlm. 201

${ }^{13}$ Dimyati dan Mudjiono. Belajar dan Pembelajaran. (Jakarta: PT. Asdi Mahasatya, 2006), hlm. 10
} hlm 259 
membantu dalam belajar karena mereka menginginkan semua anggota kelompok memperoleh keberhasilan. Perspektif perkembangan kognitif, artinya dengan adanya interaksi antara anggota kelompok dapat mengembangkan prestasi siswa untuk berfikir mengolah berbagai informasi. ${ }^{14}$

Pembelajaran kooperatif dicirikan oleh struktur tugas, tujuan, dan penghargaan kooperatif. Siswa yang belajar secara situasi kooperatif didorong untuk bekerja sama pada suatu tugas bersama dan mereka harus mengkoordinasikan usahanya untuk menyelesaikan tugasnya. Dalam penerapan pembelajaran kooperatif, dua atau lebih individu saling tergantungan satu sama lain untuk mencapai satu penghargaan bersama. Ciri-ciri yang terjadi pada kebanyakan pembelajaran yang menggunakan model pembelajaran kooperatif, adalah sebagai berikut: Siswa bekerja dalam kelompok secara kooperatif untuk menuntaskan materi belajarnya. Kelompok dibentuk dan siswa yang memiliki kemampuan tinggi, sedang dan rendah. Bilamana mungkin, anggota kelompok berasal dan ras, budaya, suku, jenis kelamin berbeda-beda. Penghargaan lebih berorientasi kelompok ketimbang individu. ${ }^{15}$

Berdasarkan ciri pembelajaran kooperatif dapat disimpulkan bahwa ciri pembelajara kooperative menekankan pada kegiatan kelompok untuk menyelesaikan masalah yang telah diberikan khususnya masalah matematika.

\section{Tujuan Pembelajaran Kooperatif}

Ide utama dari belajar kooperatif adalah siswa bekerja sama untuk belajar dan bertanggung jawab pada kemajuan belajar temannya. Menurut Slavin dalam bukunya Trianto, belajar kooperatif menekankan pada tujuan dan kesuksesan kelompok, yang hanya dapat dicapai jika semua anggota kelompok mencapai tujuan atau penguasaan materi. Johnson dan Johnson dalam bukunya Trianto menyatakan bahwa tujuan pokok belajar kooperatif adalah memaksimalkan belajar siswa untuk peningkatan prestasi akademik dan pemahaman baik secara individu maupun secara kelompok. Karena siswa bekerja dalam satu team, maka dengan sendirinya dapat memperbaiki hubungan di antara para siswa dari berbagai latar belakang etnis dan kemampuan, mengembangkan keterampilan-keterampilan kelompok dan proses pemecahan masalah. ${ }^{16}$ Berdasarkan pendapat tentang pembelajaran kooperatif dapat disimpulkan bahwa pembelajaran kooperative memaksimalkan kegiatan kelompok untuk menyelesaikan tugas dan penyelesaian masalah.

Pembelajaran kooperatif juga disusun dalam sebuah usaha untuk meningkatkan partisipasi siswa, memfasilitasi siswa dengan pengalaman sikap kepemimpinan dan membuat keputusan dalam kelompok, serta memberikan kesempatan pada siswa untuk berinteraksi dan belajar bersama-sama dengan siswa yang berbeda latar belakangnya. Jadi dalam pembelajaran kooperatif siswa berperan ganda yaitu sebagai siswa ataupun sebagai guru. Dengan bekerja

${ }^{14}$ Agus,Suprijono. Cooperative Learning, Teori dan Aplikasi PAIKEM, (Yogyakarta: PustakaPelajar, 2011), hlm. 46

\footnotetext{
${ }^{15}$ Rusman, Model-Model Pembelajaran, (Jakarta: PT. Raja Grafindo Persada, 2010),
} hlm.208-209.

${ }^{16}$ Trianto, Mendesain Model.......", hlm. 57. 
secara kolaboratif untuk mencapai sebuah tujuan bersama, maka siswa akan mengembangkan keterampilan berhubungan dengan sesama manusia yang akan sangat bermanfaat bagi kehidupan di luar sekolah.

Para ahli telah menunjukan bahwa pembelajaran kooperatif tidak hanya unggul dalam membantu siswa memahami konsep-konsep yang sulit tetapi juga berguna untuk menumbuhkan kemampuan berfikir kritis dan kemauan membantu teman. Selain itu, pembelajaran kooperatif dapat mengembangkan keterampilan sosial secara signifikan. Pembelajaran kooperatif sangat tepat digunakan untuk melatih keterampilan-keterampilan tanya jawab. Memahami konsepkonsep yang dijelaskan di atas memacu pembelajaran kooperatif untuk mencapai paling sedikit tiga tujuan penting yaitu prestasi akademis, toleransi dan penerimaan terhadap keanekaragaman keterampilan sosial. ${ }^{17}$ Maka dari itu dapat disimpulkan bahwa pembelajaran kooperative dapat membantu konsep yang mampu menumbuhkan berfikir kritis siswa dalam meningkatkan hasil belajar siswa.

\section{B. Model Pembelajaran Meaningful Interaction Design (MID) \\ 1. Pengertian Model Meaningful Interaction Design (MID)}

Istilah model banyak dipergunakan dalam pembelajaran seperti hlmnya model pembelajaran Meaning Instructional Design (MID) dimana model pembelajaran yang mengutamakan kebermaknaan belajar dan efektifivitas dengan cara membuat kerangka kerjaaktivitas secara konseptual kognitif-konstruktivis . ${ }^{18}$ Belajar bermakna ada dua hlm yang penting yang harus diperhatikan. Pertama, karakteristik bahan yang dipelajari. Kedua adalah struktur kognitif individu pembelajar. Bahan baru yang akan dipelajari tentu saja akan mengubah struktur kognitif siswa haruslah bermakna, artinya dapat berwujud istilah yang memiliki makna, konsepkonsep yang bermakana atau hubungan antara dua atau lebih konsep yang memiliki makna. Selanjutnya bahan baru yang akan dipelajari hendaknya dihubungkan dengan struktur kogntif siswa secara subtansial dan beraturan. ${ }^{19}$ Kebermaknaan belajar dan juga mampu meningkatkan kemampuan pemahaman siswa dan memungkinkan siswa untuk berbagi dengan pasangan yang berbeda dengan singkat dan teratur, selain itu siswa juga bisa bekerja dengan sesama siswa dalam suasana gotong royong dan memiliki banyak kesempatan untuk mengolah informasi dan meningkatkan keterampilan berkomunikasi. ${ }^{20}$

Menurut Ngalimun Sintak model Meaning Instructional Design (MID adalah : Lead-in dengan melakukan kegiatan yang terkait dengan pengalaman, dengan analisis pengalaman dan konsep-ide, maksudnya guru harus selalu mengaitkan pengalaman belajar dan mampu menganalisis setiap pengalamannya agar terciptanya konsep yang sesuai dengan pembelajaran, dan dapat diterapkan di dalam proses pembelajaran khusunya pada matematika. Reconstruction melakukan fasilitasi pengalaman belajar, maksudnya menjadikan tempat sarana dalam proses

\footnotetext{
${ }^{17}$ Richard I. Arends, Learning To Teach, ed.VII. buku 2, (Yogyakarta: Pustaka Belajar, 2008), hlm. 5.

18 Evalina \& Hartini. Teori Belajar dan Pembelajaran. (Bogor : Ghlmia Indonesia. 2010), hlm 40

${ }^{19}$ Ibid, hlm 42

${ }^{20}$ Anita Lie, Cooperative Learning, Mempraktekkan Cooperative Learning di Ruang-Ruang Kelas, (Jakarta: Grasindo Gramedia Widiasarana Indonesia, 2004), hlm. 65
} 
pembelajaran agar siswa dapat nyaman dalam proses pembelajaran Production melalui ekspresiapresiasi konsep, maksudnya setiap konsep harus diciptakan semenarik munkin agar siswa senang dan tidak bosan di dalam proses pembelajaran sehingga tujuan pembelajaran dapat tercapai secara maksimal. ${ }^{21}$

Berdasarkan pengertian dan sintaks model pembelajaran MID dapat disimpulkan secara umum bahwa setiap sintaks model pembelajaran Meaning Instructional Design (MID) ini mengaitkan kekreatifan guru terhadap pembelajaran agar pembelajaran terlihat lebih bermakna.

\section{Teori Belajar yang dilandasi kognitivisme dan konstruktivisme}

Teori belajar banyak dikemukakan oleh para ilmuan terhadap pendukung penelitian yang sesuai dengan idikator yang akan dicapai dalam proses peneltian. Menurut Gagne, belajar merupakan kegiatan yang kompleks. Setelah belajar orang memiliki keterampilan pengetahuan, sikap dan nilai. Stimulasi yang didapat berasa dari lingkungan dan proses kognitif yang dilakukan oleh pembelajar ${ }^{22}$. Sementara menurut Jean Piaget, proses belajar harus disesuaikan dengan tahap perkembangan kognitif yang dilalui siswa.

Menurut Brunner perkembangan kognitif seseorang terjadi melalui tiga tahap yang ditentukan oleh caranya melihat lingkungan, yaitu: Tahap enaktif, seseorang melakukan aktivitas-aktivitas dalam upayanya untuk memahami lingkungan sekitarnya. Artinya, dalam memahami dunia sekitarnya anak menggunakan pengetahuan motorik. Misalnya, melalui gigitan, sentuhan, pengangan dan sebagainya.Tahap ikonik, seseorang memahami objek-objek atau dunianya melalui gambar-gambar dan visualisasi verbal. Maksudnya, dalam memahami dunia sekitarnya anak belajar melalui bentuk perumpamaan dan perbandingan. Tahap simbolik, seseorang telah mampu memiliki ide-ide atau gagasan-gagasan abstrak yang sangat dipengaruhi oleh kemampuannya dalam berbahasa dan logika. Artinya, dalam memahami dunia sekitarnya anak belajar melalui komunikasi yang dilakukannya menggunakan banyak symbol, seperti bahasa, matematika, logika dan sebagainya. ${ }^{23}$

Menurut Vygotsky mengatakan bahwa jalan pikiran seseorang harus dimengerti dari latar sosial-budaya dan sejarahnya. Artinya, untuk memahami pikiran seseorang bukan dengan cara menelusuri apa yang ada dibalik otaknya dan pada kedalaman jiwanya, melainkan dari asal-usul tindakan sadarnya, dari interaksi sosial yang dilatari oleh sejarah hidupnya. ${ }^{24}$ Anak-anak memperoleh berbagai pengetahuan dan keterampilan melalui interaksi sosial sehari-hari. Mereka terlibat secara aktif dalam interaksi sosial dalam keluarga untuk memperoleh dan juga menyebarkan pengetahuan-pengetahuan yang telah dimilikinya.

Ausubel juga mengemukakan pendapatnya tentang teori belajar bahwa belajar dapat dikatakan menjadi bermakna jika informasi yang akan dipelajari oleh anak disusun sesuai dengan struktur kognitif yang dimiliki anak, sehingga anak dapat mengaitkan informasi barunya dengan

\footnotetext{
${ }^{21}$ Ngalimun. Strategi dan Model pembelajara.( Yogyakarta :CV Aswijaya.2014), 171

${ }^{22}$ Dimyati dan Mudjiono. 2006. Belajar dan Pembelajaran. Jakarta: PT. Asdi Mahasatya, hlm. 10

${ }^{23}$ Budiningsih, Asri C. 2005. Belajar dan Pembelajaran. Jakarta: PT. Rineka Cipta, hlm. 41

${ }^{24}$ Budiningsih, Asri C. Belajar dan Pembelajaran. (Jakarta: PT. Rineka Cipta, 2005), hlm. 99
} 
struktur kognitif yang telah dimilkinya. ${ }^{25}$ Maka dari itu bahan yang disajikan yang mengaitkan informasi barunya telah disusun secara final. Jadi anak belajar dengan menerima bahan yang telah disusun secara final dan pengajar menyampaikan dengan metode ceramah. Bahan pelajaran yang disajikan itu harus bermakna, sehingga mudah diserap oleh anak.

\section{Meaningful Learning (Belajar Bermakna)}

Belajar bermakna ada dua halaman yang penting yang harus diperhatikan. Pertama, karakteristik bahan yang dipelajari. Kedua adalah struktur kognitif individu pembelajar. ${ }^{26}$ Karakteristik yang dimaksudkan pembelajaran harus bersifat membangun pengetahuan siswa dengan cara menciptakan pembejaran yang kreatif dan menyenangkan, serta pembelajaran harus pula senantiasa teratur agar tidak terjadi kebingungan dalam memaknai suatu konsep pembelajaran.

Konsep pembelajaran haruslah bersifat baru yang akan mengubah struktur kognitif siswa menjadi bermakna, artinya dapat berwujud istilah yang memiliki makna, konsep-konsep yang bermakana atau hubungan antara dua atau lebih konsep yang memiliki makna. Bahan baru yang berisikan informasi baru hendaknya dihubungkan dengan struktur kogntif siswa secara subtansial dan beraturan. Subtansial artinya bahan yang dihubungkan harus sejenis atau sama subtansinya dengan yang sudah ada pada struktur kognitif, yang mengikuti aturan sesuai dengan sifat bahan tersebut (karakteristik pengetahuan baru yang diperkenalkan pada pengetahuan siswa), ${ }^{27}$ maka dengan itu hlm yang menentukan adalah siswa harus memiliki kemauan untuk menggabungkan konsep baru tersebut dengan strutur kognitifnya sendiri secara subtansial dan beraturan pula.

Siswa dapat memahami isi lebih bermakna, maka disarankan menggunakan pendekatan pembelajaran yang berorientasi pada masalah. Pebelajar difasilitasi untuk dapat mengakses berbagai informasi (pengetahuan, ketrampilan, dan sikap) dalam rangka menyelesaikan masalah. Penyelesaian masalah tersebut menggunakan berbagai sumber daya informasi, misalnya media cetak, media audio, media audio visual, multimedia, internet, dan teknologi terpadu. Hlm ini berbeda dengan pengembangan pembelajaran yang berpijak pada teori behavioristik, maka dari itu pengembangan pembelajaran diarahkan pada penyelesaian tugas atau penguasaan pengetahuan secara sistematik (bagian demi bagian secara terpisah). Teori Behavioristik menekankan pada subskill yang diajarkan.

\section{Pembelajaran lebih ditekankan pada kontek dan pemahamam individu yang lebih bermakna (meaningful).}

Pembelajaran siswa dapat memahami isi lebih bermakna, maka disarankan menggunakan pendekatan pembelajaran yang berorientasi pada masalah. Pebelajar difasilitasi untuk dapat mengakses berbagai informasi (pengetahuan, ketrampilan, dan sikap) dalam rangka

\footnotetext{
${ }^{25}$ Paimin, joule Ekaningsih. Agar Anak Pintar Matematika. (Jakarta: Puspa Swara, 1998), hlm. 15

${ }^{26}$ Budiningsih, Asri C. 2005. Belajar dan Pembelajaran. Jakarta: PT. Rineka Cipta, hlm. 60

${ }^{27}$ Ngalimun. Strategi dan Model Pembelajaran. (Yogyakarta: Presindo. 2014), hlm 171
} 
menyelesaikan masalah. Penyelesaian masalah tersebut menggunakan berbagai sumber daya informasi, misalnya media cetak, media audio, media audio visual, multimedia, internet, dan teknologi terpadu. Hlm ini berbeda dengan pengembangan pembelajaran yang berpijak pada teori behavioristik, pengembangan pembelajaran diarahkan pada penyelesaian tugas atau penguasaan pengetahuan secara sistematik (bagian demi bagian secara terpisah).

Pembelajaran bermakna memiliki kondisi-kondisi sebagai berikut: Menjelaskan hubungan atau relevansi bahan-bahan baru dengan bahan-bahan lama. Menunjukkan persamaan dan perbedaan antara bahan baru dengan bahan lama. Lebih dahulu memberikan ide yang paling umum kemudian hlm-hlm yang lebih terperinci Mengusahakan agar ide yang telah ada dikuasai sepenuhnya sebelum ide yang baru disajikan. ${ }^{28}$ Maka dari itu pembelajaran bermakna dapat disimpulakan sebagai pembelajaran yang menghubungkan pengetahuan lama dengan pengetahuan baru yang didapatnya.

\section{Langkah-langkah kegiatan yang mengarah pada timbulnya pembelajaran bermakna}

Langkah-langkah kegiatan pembelajaran bermakna sebagai berikut: ${ }^{29}$

a) Orientasi mengajar tidak hanya pada segi pencapaian prestasi akademik, melainkan juga diarahkan untuk mengembangkan sikap dan minat belajar serta potensi dasar siswa.

b) Topik-topik yang dipilih dan dipelajari didasarkan pada pengalaman anak yang relevan. Pelajaran tidak dipersepsi anak sebagai tugas atau sesuatu yang dipaksakan oleh guru, melainkan sebagai bagian dari atau sebagai alat yang dibutuhkan dalam kehidupan anak.

c) Metode mengajar yang digunakan harus membuat anak terlibat dalam suatu aktivitas langsung dan bersifat bermain yang menyenangkan.

d) Dalam proses belajar perlu diprioritaskan kesempatan anak untuk bermain dan bekerjasama dengan orang lain.

e) Bahan pelajaran yang digunakan hendaknya bahan yang dapat dipahami siswa

f) Dalam menilai hasil belajar siswa, para guru tidak hanya menekankan aspek kognitif dengan menggunakan tes tulis, tetapi harus mencakup semua domain perilaku anak yang relevan dengan melibatkan sejumlah alat penilaian.

Jadi dapat disimpulkan bahwa pembelajaran senantiasa melibatkan siswa dan menekankan siswa terhadap aspek kognitifnya agar siswa mampu meningkatkan hasil belajar.

\section{Kelebihan dan kekurangan Model MID}

Dalam model pembelajaran MID terdapat kelebihan dan kelemahan di saat proses pembelajaran diantaranya, kelebihan Sebagai jembatan menghubungkan tentang apa yang sedang dipelajari siswa.Mampu membantu siswa untuk memahami bahan belajar secara lebih

\footnotetext{
${ }^{28}$ Evalina \& Hartini. 2010. Teori Belajar dan Pembelajaran. Bogor : Ghlmia Indonesia. Hlm 54

${ }^{29}$ Ibid hlm 59
} 
mudah. Membantu siswa untuk mengembangkan pengertian dan pemahaman konsep secara lengkap Membantu siswa membentuk, mengubah, diri atau mentransformasikan informasi baru. Informasi yang dipelajari secara bermakna lebih lama dapat diingat. Informasi yang dipelajari secara bermakna memudahkan proses belajar berikutnya untuk materi pelajaran yang mirip. Informasi yang dipelajari secara bermakna mempermudah belajar hlm-hlm yang mirip walaupun telah terjadi lupa. Sefangkan Kekurangan Guru merasa kesulitan dalam memberikan contohnya bersifat nalar untuk mendapatnya contoh yang baru Karena ini membentuk suatu kelompok maka hlm sering terjadi adalah mengandalkan siswa yang pintar. ${ }^{30}$

Berdasarkan Kelebihan dan kekurangan model MID tersebut dapat disimpulan bahwa model MID menekankan padan pembelajaran bersama dan membantu siswa saling bertukar fikiran dalam proses penyelesaian masalah.

\section{Penelitian yang Relevan}

Desak Made Agung Ratih Rosmila sari dalam penelitiannya yang berjudul pengaruh penerapan model pembelajaran MID berbantuan Media teka teki silang dan motivasi berprestasi terhadap hasil belajar IPS siswa kelas V SD Gugus Untung Surapati Denpasar Timur yang menyatakan terdapat pengaruh yang signifikan hasil belajar dengan besar hipotesisnya $4,37 .{ }^{31}$

Penelitian lain dengan model pembelajaran yang sama juga dilakukan oleh Masruhan Mufidin model pembelajaran MID dapat meningkatkan hasil belajar siswa dengan rata-rata niai tes akhir siklus 1 dari 64,11 menjadi 76,63 pada siklus 2 dan ketuntasan belajar klasikal meningkat pada siklus 1 sebesar 68,4\% menjadi 77,5\% pada siklus $2 .{ }^{32}$ Kedua penelitian yang telah dilakukan sebelumnya memiliki perbedaan pada hasil belajar yang peneliti menyesuaikan pada indikator materi yang akan diuji cobakan sesuai dengan sintaks atau langkah-langkah model pembelajaran MID.

Berdasarkan penelitian sebelumnya dapat disimpulkan bahwa model MID dapat meningkat hasil belajar, maka dari itu peneliti menggunakan model MID di sampel yang berbeda pada sisa MTsN Kota Langsa.

\section{Hasil Belajar}

\section{Pengertian Hasil Belajar}

Hasil belajar terdiri dari dua kata yaitu "Hasil" dan "Belajar". Hasil merupakan akibat dari yang ditimbulkan karena berlangsungnya suatu proses kegiatan. Menurut kusnandar, hasil belajar adalah kemampuan siswa dalam memenuhi suatu tahapan pencapaian pengalaman belajar dalam suatu kompetensi dasar. ${ }^{33}$ Sesuai dengan pendapat Dimyati yang mengatakan bahwa

${ }^{30}$ Ngalimun. Strategi dan Model pembelajara.( Yogyakarta :CV Aswijaya.2014), 180

${ }^{31}$ Made, Desak. Ada pengaruh penerapan model pembelajaran MID berbantuan Media teka teki silang dan motivasi berprestasi terhadap hasil belajar IPS siswa kelas V SD Gugus Untung Surapati (Denpasar Timur.2014. Jurnal Vol 2 No: 1 tahun 2014)

32 Masruhan. (Meningkatkan Hasil Belajar Matematika Pada Pokok Bahasan Operasi Hitung Bentuk Aljabar Melalui Model pembelajaran MID Pada Siswa Kelas VII-A Mts Islamiyah Sumpiuh - Banyumas Tahun Pelajaran 2006/2007.Jurnal tahun 2007 diakses 10 Mei 2017

${ }^{33}$ Kunandar. Guru Profesional, Impementasi Kurikulum Tingkat Satuan Pendidikan (KTSP) dan Sukses dalam Sertifikasi Guru. (Jakarta: PT. Raja Grafindo Persada, 2008), hlm. 251 
"hasil belajar merupakan hasil dari suatu interaksi tindak mengajar atau tindak belajar". ${ }^{34}$ Setelah belajar siswa akan memperoleh hasil atau nilai ukur untuk kemampuannya. Hasil dari belajar tersebut tidak diperoleh begitu saja, namun didapat setelah siswa mengalami proses pembelajaran terlebih dahulu.

Hasil pada dasarnya merupakan sesuatu yang diperoleh dari suatu aktivitas, sedangkan belajar merupakan suatu proses yang mengakibatkan perubahan pada individu, yakni perubahan tingkah laku, baik aspek pengetahuannya, keterampilannya, maupun aspek sikapnya. Hasil belajar merupakan istilah yang digunakan untuk menunjukkan tingkat keberhasilan yang dicapai oleh seseorang setelah melakukan usaha tertentu. Hasil belajar ini diperoleh siswa setelah mengikuti proses belajar mengajar. Untuk mengetahui tingkat pencapaian hasil belajar siswa atau kemampuan siswa dalam suatu pokok bahasan guru biasanya mengadakan tes hasil belajar. Hasil belajar dinyatakan dalam bentuk skor yang diperoleh siwa setelah mengikuti suatu tes hasil belajar yang diadakan setelah selesai program pengajaran. Proses penilaian terhadap hasil belajar dapat memberikan informasi kepada guru. Berdasarkan informasi tersebut guru dapat menyusun dan membina kegiatan-kegiatan siswa lebih lanjut, baik untuk keseluruhan kelas maupun individu.

Belajar adalah proses perubahan tingkah laku atau penampilan, dengan serangkaian kegiatan misalnya dengan membaca, mengamati, mendengarkan, meniru dan lain sebagainya. Belajar juga akan lebih baik, kalau si subjek belajar itu mengalami atau melakukannya se ndiri. ${ }^{35}$ Siswa adalah penentu terjadi atau tidak terjadinya proses belajar. Proses belajar terjadi berkat siswa memperoleh sesuatu yang ada di lingkungan sekitar, maka dari itu peneliti menyimpulkan bahwa lingkungan yang di pelajari oleh siswa berupa keadaan alam, benda-benda, hewan, tumbuh-tumbuhan, manusia, atau hlm-hlm yang dijadikan masalah belajar.

Beberapa pendapat para ahli pendidikan tentang pengertian belajar yang berbeda, namun mengacu pada prinsip yang sama. Cronbach menyatakan bahwa belajar merupakan suatu perubahan sebagai hasil dari pengalaman. Sedangkan menurut Winkel, belajar adalah suatu aktivitas yang berlangsung dalam interaksi aktif dengan lingkungan, yang menghasilkan perubahan-perubahan dalam pengetahuan, keterampilan dan sikap. ${ }^{36}$ Sedangkan menurut Lester D. Crow dan Alice Crow dalam Mulyasa mendefinisikan bahwa belajar adalah "Suatu perubahan dari tidak tahu menjadi tahu, dari tidak bisa menjadi bisa, dari kurang baik menjadi baik melalui aktivitas, praktik dan pengalaman. ${ }^{37}$ Berdasarkan pengertian tentang belajar dapat disimpulkan bahwa belajar merupakan proses perubahan sikap dan tindakan dalam menupayakan hasil yang lebih baik.

Belajar juga dapat dilakukan di dalam maupun di luar kelas. Pengalaman belajar di dalam kelas dilaksanakan dalam kegiatan pembelajaran dengan mengadakan interaksi antara siswa

\footnotetext{
${ }^{34}$ Dimyati dan Mudjiono. Belajar dan Pembelajaran. (Jakarta: PT. Asdi Mahasatya, 2006) hlm. 3

${ }^{35}$ Riyanto, Yatim. Paradigma Baru Pembelajaran. (Jakarta: PT. Kencana Prenada Media Group, 2010), hlm. 5

${ }^{36}$ Djamarah S. B. Pendekatan dan Metode Pembelajaran. http://Smacepiring. Wordpress. Com / 2008 / 02 / $19 /$ Pendekatan dan Metode Pembelajaran /, 5 September 2016

${ }^{37}$ Kunandar. Guru Profesional, Impementasi Kurikulum Tingkat Satuan Pendidikan (KTSP) dan Sukses dalam Sertifikasi Guru. (Jakarta: PT. Raja Grafindo Persada, 2008) hlm. 319
} 
dengan sumber belajar. Pengalaman belajar di luar kelas dapat berupa kegiatan seperti telaah buku, mengadakan percobaan di laboratrium, dan sebagainya. ${ }^{38}$ Dengan kata lain, belajar adalah suatu proses untuk memperoleh pengetahuan melalui pengalaman yang di dapat dari lingkungan sekitar sehingga yang bersangkutan mengalami perubahan pengetahuan, sikap dan keterampilan.

Berdasarkan pengertian tentang belajar dapat disimpulkan bahwa belajar merupakan proses perubahan sikap dan tindakan dalam menupayakan hasil yang lebih baik

\section{Faktor-faktor yang Mempengaruhi Hasil Belajar}

Faktor-faktor yang mempengaruhi hasil belajar siswa dapat dibedakan sebagai berikut:

\section{a. Faktor Internal (faktor dari dalam individu yang belajar)}

Faktor internal adalah faktor yang berasal dari dalam diri siswa itu sendiri. Adapun hlmhlm yang mempengaruhi hasil belajar tersebut yaitu Intelegensi Menurut Wechler, intelegensi adalah suatu kecakapan global atau rangkuman kecakapan untuk dapat bertindak secara terarah, berfikir secara baik, dan bergaul dengan lingkungan secara efisien. Kecakapan tersebut menjadi nyata apabila siswa memecahkan masalah dalam belajar atau dalam kehidupan seharihari.Konsentrasi Belajar merupakan kemampuan memusatkan perhatian pada pelajaran. Pemusatan perhatian tertuju pada isi bahan belajar maupun proses memperolehnya. Untuk memperkuat perhatian pada pelajaran, guru perlu menggunakan bervariasi metode mengajar, dan memperhitungkan waktu belajar serta istirahat. Rasa Percaya Diri Siswa timbul dari keinginan mewujudkan diri bertindak dan berhasil. Rasa percaya diri dapat timbul berkat adanya pengakuan dari lingkungan. Dalam proses belajar mengajar diketahui bahwa unjuk prestasi merupakan pembuktian perwujudan diri yang diakui oleh guru dan teman siswa. Makin sering siswa berhasil menyelesaikan tugas, maka semakin banyak pengakuan umum diperoleh sehingga rasa percaya diri semakin kuat. Kebiasaan Belajar Kegiatan sehari-hari ditemukan adanya kebiasaan belajar yang kurang baik. Kebiasaan tersebut antara lain berupa (1) belajar pada akhir semester, (2) belajar tidak teratur, (3) menyia-nyiakan kesempatan belajar, (4) bersekolah hanya untuk bergengsi, (5) bergaya jantan seperti merokok, sok menggurui teman lain dan (6) bergaya minta "belas kasihan" tanpa belajar. Kebiasaan tersebut disebabkan oleh ketidakmengertian siswa pada arti belajar bagi diri sendiri. Hlm ini dapat diperbaiki dengan membelajarkan disiplin pada diri siswa. ${ }^{39}$

\section{b. Faktor Eksternal (faktor dari luar individu yang belajar)}

Faktor eksternal adalah faktor yang berasal dari luar diri siswa itu sendiri. Pencapaian tujuan belajar perlu diciptakan adanya sistem lingkungan belajar yang kondusif. Adapun faktorfaktor eksternal yang mempengaruhi mencakup hlm-hlm berikut:

${ }^{38}$ Kunandar. Guru Profesional, Impementasi Kurikulum Tingkat Satuan Pendidikan (KTSP) dan Sukses dalam Sertifikasi Guru. (Jakarta: PT. Raja Grafindo Persada, 2008), hlm. 255

${ }^{39}$ Kunandar,. Guru Profesional, Impementasi Kurikulum Tingkat Satuan Pendidikan (KTSP) dan Sukses dalam Sertifikasi Guru. (Jakarta: PT. Raja Grafindo Persada, 2008), hlm. 255 
Guru adalah pengajar yang mendidik. Guru tidak hanya mengajar bidang studi yang sesuai dengan keahliannya, tetapi juga menjadi pendidik generasi muda bangsanya. Sebagai pendidik, guru memusatkan perhatian kepada kepribadian siswa. Sebagai guru yang mengajar, ia bertugas mengelola kegiatan belajar siswa di sekolah. Prasarana dan Sarana Pembelajaran meliputi gedung sekolah, ruang belajar, lapangan olahraga, ruang ibadah, ruang kesenian dan peralatan olahraga. Sedangkan sarana pembelajaran meliputi buku pelajaran, buku bacaan, alat dan fasilitas laboratorium sekolah, dan berbagai media pengajaran yang lain. Lengkapnya prasarana dan sarana sangat menentukan proses belajar yang baik. Kebijakan PenilaianHasil belajar merupakan hasil proses belajar. Hasil belajar dinilai dengan ukuran-ukuran guru, tingkat sekolah dan tingkat nasional. Dengan ukuran-ukuran tersebut, seorang siswa dapat digolongkan lulus atau tidak. Dari segi proses belajar, jika digolongkan lulus maka proses belajar siswa dan kegiatan mengajar guru dihentikan sementara. Jika digolongkan tidak lulus, terjadilah proses belajar ulang bagi siswa dan mengajar ulang bagi guru. Keputusan hasil belajar merupakan puncak harapan siswa. Secara kejiwaan, siswa terpengaruh tentang hasil belajarnya. Lingkungan sosial dapat mempengaruhi semangat belajar seorang siswa. Para guru yang selalu menunjukkan sikap dan perilaku yang simpatik dan memperlihatkan suri teladan yang baik dan rajin dalam hlm belajar, akan menjadi daya dorong yang positif bagi kegiatan belajar siswa. Selanjutnya, yang termasuk lingkungan sosial siswa adalah masyarakat dan tetangga juga teman-teman sepermainan disekitar tempat tinggal siswa tersebut. Namun, lingkungan sosial yang lebih banyak mempengaruhi kegiatan belajar siswa ialah orang tua dan keluarga siswa itu sendiri. Sifat-sifat orang tua, praktik pengelolaan keluarga, ketegangan keluarga, semuanya dapat memberi dampak baik atau buruk terhadap kegiatan belajar dan hasil belajar yang ingin dicapai. $^{40}$

\section{Kerangka Berpikir}

Perubahan yang sangat mendasar dalam pendidikan matematika adalah pergeseran dalam pemahaman bagaimana siswa belajar matematika. Belajar matematika tidak lagi dipandang sebagai pemberian informasi yang berupa sekumpulan teori, definisi maupun hitung menghitung yang kemudian disimpan dalam memori siswa yang diperoleh melalui praktik yang diulang-ulang melainkan membelajarkan siswa dengan inovasi penyampaian pembelajaran melalui model-model pembelajaran yang menarik minat siswa seperti pembelajaran kelompok dengan menggunakan teknologi, agar siswa dapat lebih memahami masalah matematik dan dapat menjelaskan kepada orang lain.

Untuk dapat mencapai tujuan pembelajaran tersebut diupayakan guru dapat memilih model pembelajaran yang tepat dalam proses pembelajarannya. Salah satu model pembelajaran adalah model pembelajaran C-MID. Dalam pembelajaran C-MID, siswa dapat membentuk kelompok atau secara individu untuk menyelesaikan suatu masalah, Sehingga siswa lebih mudah memahami dan mengingat konsep-konsep yang telah ditemukan sendiri atas pengalaman yang didapatkan dengan pembelajaran.

${ }^{40}$ Ibid, hlm 257 


\section{E. Materi Segi Tiga}

\section{Implementasi Materi Segitiga}

Bangun datar adalah bangun 2 ( dua ) dimensi yang hanya memiliki panjang dan lebar serta dibatasi oleh garis lurus atau lengkung. Beberapa pakar matematika mendefinisikan bangun datar sebagai berikut :

1. Bangun datar adalah bagian dari bidang datar yang dibatasi oleh garis - garis lurus atau lengkung.

2. Bangun datar dapat didefinisikan sebagai bangun yang rata yang mempunyai 2 dimensi yaitu panjang dan lebar, tetapi tidak mempunyai tinggi atau tebal

\section{Segitiga}

Segitiga adalah bangun datar yang dibatasi oleh 3 ( tiga ) buah ruas garis. Ketiga ruas garis tersebut disebut dengan sisi - sisi dari segitiga itu. Sehingga segitiga pasti juga memiliki 3 buah titik sudut.

Jenis - jenis segitiga ditinjau dari panjang sisi - sisinya :

1. Segitiga sama sisi : ketiga sisinya sama panjang

2. Segitiga sama kaki : kedua sisi di antaranya sama panjang

3. Segitiga sebarang : ketiga sisinya berbeda panjang Jenis - jenis segitiga ditinjau dari besar sudut - sudutnya :

1. Segitiga lancip: semua sudutnya kurang dari 90 derajat

2. Segitiga tumpul : salah satu sudutnya lebih dari 90 derajat

3. Seitiga siku - siku : salah satu sudutnya 90 derajat

4. Keliling = penjumlahan panjang semua sisinya

5. Luas $=($ alas $x$ tinggi $): 2$

\section{Alat Peraga Segitiga Menghitung Luas}

Langkah - langkah penggunaan, Letakan pada papan gabus model daerah segitiga Dengan cara menghimpitkan model segitiga ditunjukan bahwa kedua bangun tersebut kongruen, kemudian tanyakan kepada peserta didik, , Sambil menunjuk pada bangun bahwa segitiga ini alasnya $a$, tingginya $t$ kemudian sambil menunjuk bangun tanyakan kepada peserta didik, Perhatikan bahwa bangun ini dipotong melalui tengah - tengah garis tinggi dan sejajar alas (guru menunjuk $1 / 2$ tinggi yang dipotong kemudian tanyakan kepada peserta didik)

\section{LKS Segitiga}

Dalam lembar kerja ini mengikuti langkag-Langkah Pembelajaran Meaningful Intructional Design Yang memiliki 3 tahapat pembelajaran yang dituangkan didalam lembar kerja siswa dalam menentukan sifat dan luas pada materi segitiga dan diaplikasikan dengan alat peraga kekekalan luas pada materi segitiga.

\section{METODE PENELITIAN}




\section{A. Lokasi dan Waktu Penelitian}

Penelitian ini dilakukan di MTsN Langsa beralamatkan di jalan Ahmad Yani Kp. Baro Langsa Lama, dan dilaksanakan pada pada tanggal 15 Mei sampai dengan 22 Mei Tahun Ajaran 2016/2017 di semester II dikarenakan materi segitiga pada semester genap dan sesuai dengan proses pembelajaran yang terdapat di MTsN Langsa

\section{B. Populasi dan Sampel}

Populasi dalam penelitian ini adalah seluruh siswa kelas VII MTsN Langsa Tahun Ajaran 2016/2017 yang terdiri dari 8 kelas yang berjumlah 211 siswa, Mengingat jumlah populasi yang sangat besar maka penulis mengambil sampel secara acak. Pengambilan sampel dilakukan dengan menggunakan teknik Simple Random Sampling. Simple Random Sampling yaitu teknik sampling yang dilakukan secara acak dengan menggunakan undian, ordinal, tabel bilangan random, atau komputer ${ }^{41}$. Pengambilan sampel pada penelitian ini dengan menggunakan teknik undian yaitu dengan membuat gulungan kertas yang berisi semua populasi dari semua kelas VII, kemudian diambil dua gulungan kertas, gulungan kertas yang pertama sebagai kelas eksperimen yaitu kelas VII.5 dan gulungan kertas kedua sebagai kelas kontrol yaitu kelas VII.6.

\section{Metode dan Variabel Penelitian}

\section{Metode Penelitian}

Dalam penelitian ini peneliti menggunakan pendekatan penelitian kuantitatif dengan metode eksperimen. Penelitian ini menggunakan rancangan penelitian Desain Randomized Control Group Pretest-posttest dengan menggunakan pembagian dua kelompok penelitian yaitu kelompok penelitian eksperimen dengan menggunakan pembelajaran Cooperative Meaning Instructional Design (C -MID) dan kelompok penelitian kontrol tanpa menggunakan pembelajaran Cooperative Meaning Instructional Design (C-MID) sebagaimana digambarkan pada tabel berikut:

Tabel Rancangan Penelitian Desain Randomized Control Group Pretest Posttest

\begin{tabular}{|c|c|c|c|}
\hline Kelompok & $\begin{array}{c}\text { Pengukuran } \\
\text { (Pretest) }\end{array}$ & Perlakuan & $\begin{array}{c}\text { Pengukuran } \\
\text { (Posttest) }\end{array}$ \\
\hline Eksperimen & $\mathrm{T}_{\mathrm{o}}$ & $\mathrm{X}$ & $\mathrm{T}_{\mathrm{I}}$ \\
\hline Kontrol & $\mathrm{T}_{\mathrm{o}}$ & - & $\mathrm{T}_{\mathrm{I}}$ \\
\hline
\end{tabular}

\section{Keterangan:}

$\mathrm{T}_{\mathrm{o}}=$ Hasil pretest kelas eksperimen dan kelas kontrol

$\mathrm{T}_{\mathrm{I}}=$ Hasil posttest kelas eksperimen dan kelas kontrol

$\mathrm{X}=$ Menggunakan Model Pembelajaran Cooperative Meaning Instructional Design (C-MID)

\footnotetext{
${ }^{41}$ Suharsimi Arikunto, 2010. Prosedur Penelitian, Yogyakarta: Rineka Cipta. hlm.189
} 


\section{Variabel Penelitian}

Variabel adalah segala sesuatu yang dijadikan objek penelitian. ${ }^{42}$ Dalam penelitian ini peneliti menggunakan dua variabel, yaitu :

a. Variabel Bebas: Model Pembelajaran Cooperative Meaning Instructional Design

b. Variabel Terikat: Hasil Belajar

\section{Teknik Pengumpulan Data dan Instrumen Penelitian}

\section{Teknik Pengumpulan Data}

Data dalam penelitian ini akan diperoleh dengan menggunakan metode pengumpulan data berupa tes. Tes digunakan untuk memperoleh data tentang pemahaman matematik dari siswa sampel penelitian. Teknik pengumpulan data yang dilakukan pada penelitian ini menggunakan tahapan-tahapan sebagai berikut :

a. Memberikan soal pretest pada kelas eksperimen untuk mengetahui penguasaan konsep siswa sebelum diberi perlakuan.

b. Memberikan perlakuan kepada kelas eksperimen dengan menggunakan model pembelajaran Cooperative Meaningful Instructional Design (C-MID)

c. Memberikan soal Posttest pada kelas eksperimen untuk mengetahui hasil belajar setelah diberi perlakuan.

\section{Instrumen Penelitian}

\section{a. Validitas}

Untuk menghitung validitas test dalam penelitian ini digunakan rumus Pearson Product Moment, ${ }^{43}$

Keterangan:

$r_{x y} \quad=$ Koefisien Korelasi

$\sum X=$ Jumlah skor item

$\sum Y \quad=$ Jumlah skor total (seluruh item)

$\mathrm{N} \quad=$ Jumlah responden

Berdasarkan hasil perhitungan validitas butir soal (lampiran 4), diperoleh hasil :

\section{b. Reliabelitas Instrumen}

Untuk mengetahui reliabelitas instrument peneliti menggunakan rumus alpha ${ }^{44}$ yaitu sebagai berikut:

\footnotetext{
${ }^{42}$ Russefendi, Dasar-dasar Penelitian Pendidikan dan Bidang Non-Eksata Lainnya, (Semarang: IKIP. 1994) .hlm. 78

${ }^{43}$ Suharsimi ,Arikunto. 2005. Dasar-dasar Evaluasi Pendidikan. Jakarta: Bumi Aksara. hlm.73.

${ }^{44}$ Arikunto, Suharsimi. 2009. Dasar-dasar Evaluasi Penelitian, Jakarta: Bumi Aksara, hlm. 109
} 
c.

$\mathrm{r}_{\mathrm{II}}=\left(\frac{n}{n-1}\right)\left(1-\frac{\sum \sigma_{i}^{2}}{{\sigma_{i}}^{2}}\right)$

d.

Keterangan:

$\mathrm{r}_{\text {II }} \quad$ : reliabelitas yang dicari

$\sum \sigma_{i}^{2}$ : Jumlah varians skor tiap-tiap item

$\sigma_{i}^{2} \quad:$ Varians total

$n$ : Banyaknya item

Dengan rumus varians ${ }^{45}$ :

$\sigma^{2}=\frac{\sum X^{2}-\frac{\left(\sum X\right)^{2}}{N}}{N}$

Distribusi (Tabel r) untuk $\alpha=0,05$ dan derajat kebebasan $(\mathrm{dk}=\mathrm{n}-1)$

Kaidah keputusan:

Jika $r_{I I} \geq r_{\text {tabel }}$ berarti reliabel, sebaliknya

Jika $r_{I I}<r_{\text {tabel }}$ berarti tidak reliabel.

Berdasarkan hasil pengujian pada lampiran 6 diperoleh nilai $r_{I I}=0,821$ sedangkan nilai $r_{\text {tabel }}=0,413$ atau $\mathbf{r}_{\text {hitung }} \geq \mathbf{r}_{\text {tabel }}$. Jadi dapat disimpulkan bahwa tes tersebut dinyatakan reliabel. Jadi, instrument memenuhi syarat untuk pengumpulan data dalam penelitian ini.

\section{c.Daya Pembeda}

Daya pembeda soal digunakan untuk mengetahui tingkat kemampuan siswa dalam menjawab soal dan juga untuk menentukan apakah soal tersebut layak atau cocok untuk diberikan selanjutnya kepada siswa lain. Hlm ini dapat dilihat dari banyaknya siswa yang bisa menjawab dengan benar.

Russfendi dalam Asep Jihad dan Abdul Haris Untuk menghitung daya pembeda soal digunakan rumus ${ }^{46}$.

$$
D P=\frac{S_{A-} S_{B}}{\frac{1}{2} n \cdot m a k s}
$$

Keterangan:

$\mathrm{S}_{\mathrm{A}} \quad=$ Jumlah Skor Kelompok Atas Pada Butir Soal Yang Diolah

${ }^{45}$ Ibid, hlm 110

${ }^{46}$ Asep Jihad \& Abdul Haris. 2008. Evaluasi Pembelajaran. Yogyakarta: multi pressindo. hlm 189. cetak 1 
$\mathrm{S}_{\mathrm{B}} \quad=$ Jumlah Skor Kelompok Bawah Pada Butir Soal Yang Diolah

$\mathrm{n} \quad=$ Jumlah Siswa Kelompok Atas Dan Kelompok Bawah

maks = skor maksimal soal yang bersangkutan

Klasifikasi interpretasi untuk daya pembeda soal yang digunakan menurut Guilford dalam Suherman adalah sebagai berikut: ${ }^{47}$ dapat diketahui bahwa dari 5 butir soal tes yang penulis buat, tidak terdapat soal yang daya pembedanya jelek. Oleh karena itu, penulis menggunakan semua butir soal tersebut sebagai instrumen untuk mengukur hasol belajar siswa.

\section{d. Tingkat Kesukaran}

Taraf kesukaran soal yaitu kemampuan tes dalam menyaring banyaknya subjek peserta tes yang mengerjakan dengan benar. Untuk menghitung taraf kesukaran soal tersebut digunakan rumus Sudjana dalam Asep Jihad dan Abdul Haris ${ }^{48}$ :

$$
T K=\frac{S_{A+} S_{B}}{n \cdot m a k s}
$$

Keterangan:

$\mathrm{S}_{\mathrm{A}} \quad=$ Jumlah Skor Kelompok Atas Pada Butir Soal Yang Diolah

$\mathrm{S}_{\mathrm{B}} \quad=$ Jumlah Skor Kelompok Bawah Pada Butir Soal Yang Diolah

$\mathrm{n} \quad=$ Jumlah Siswa Kelompok Atas Dan Kelompok Bawah

maks = skor maksimal soal yang bersangkutan.

Selanjutnya taraf kesukaran yang diperoleh diinterpretasikan dengan menggunakan kriteria menurut Guilford dalam Suherman sesuai tabel berikut : ${ }^{49}$

\section{E. Rancangan Penelitian}

Secara lengkap, untuk memberikan gambaran yang lebih terperinci mengenai prosedur penelitian yang dilaksanakan dalam penelitian ini, berikut disajikan rangkuman alur kerja dan alur prosedur penelitiannya terlampir dalam bentuk langkah-langkah.

\section{F. Teknik Analisis Data}

Setelah data penelitian diperoleh, maka dilakukan pengolahan dan analisis menggunakan langkah-langkah sebagai berikut :

\footnotetext{
${ }^{47}$ Suherman, E. 2003. Evaluasi Pembelajaran Matematika. Bandung: JICA UPI. hlm.161.

${ }^{48}$ Asep,Jihad dkk.2008. Evaluasi Pembelajaran. Yogyakarta: multi pressindo. cetak $1 \mathrm{hlm} 182$

${ }^{49}$ Suherman, E. 2003. Evaluasi Pembelajaran Matematika. Bandung:JICA UPI,hlm 170
} 


\section{Uji Normalitas}

Uji normalitas dilakukan untuk mengetahui apakah data berasal dari populasi yang berdistribusi normal atau tidak. Dalam uji normalitas ini, penulis akan menggunakan uji normalitas Chi Kuadrat $X^{2}$. Riduwan dan H. Sunarto menyebutkan bahwa; "Metode Chi Kuadrat $\chi^{2}$ digunakan untuk mengadakan pendekatan dari beberapa faktor atau mengevaluasi frekuensi yang diselidiki atau frekuensi hasil observasi $\left(f_{o}\right)$ dengan frekuensi yang diharapkan $\left(f_{e}\right)$ dari sampel apakah terdapat hubungan atau tidak" ${ }^{\prime 50}$. Untuk menguji normalitas data, menurut Riduwan digunakan rumus: $X^{2}=\sum \frac{\left(f_{0}-f_{e}\right)^{2}}{f_{e}} \quad 51$; selanjutnya dari dengan membandingkan $\chi_{\text {hitung }}^{2}$ dan $\chi_{\text {tabel }}^{2}$; dengan $\alpha=0,05 \mathrm{dan} \mathrm{dk}=\mathrm{n}-1$, jika $\chi^{2}{ }_{\text {hitung }}<\chi_{\text {tabel. }}^{2}$ maka dapat disimpulkan bahwa data hasil tes berdistribusi normal.

\section{Uji Homogenitas}

Uji homogenitas digunakan untuk mengetahui apakah dua sampel yang diambil mempunyai varians yang homogen atau tidak. untuk menguji homogenitas varians, penulis akan menggunakan dimana rumus :

$$
\mathrm{F}_{\text {hitung }}=\frac{\text { Varians terbesar }}{\text { Varians terkecil }}_{52}
$$

Kriteria pengujian pada taraf signifikansi $\alpha=0,05$ dan derajat kebebasan $(\mathrm{dk}=\mathrm{n}-1)$ adalah : Jika $\mathbf{F}_{\text {hitung }}<\mathbf{F}_{\text {tabel }}$ berarti kedua varians kelas eksperimen dan kontrol adalah homogen.

\section{Uji Hipotesis}

Dalam penelitian ini, untuk menguji hipotesis penulis menggunakan statistik uji- $\mathrm{t}^{53}$, yaitu:

$$
\mathrm{t}_{\mathrm{h}}=\frac{\bar{x}_{1}-\bar{x}_{2}}{S \sqrt{\frac{1}{n_{1}}+\frac{1}{n_{2}}}} ; \operatorname{dimana} \mathrm{S}^{2}=\frac{\left(n_{1}-1\right) S_{1}{ }^{2}+\left(n_{2}-1\right) S_{2}{ }^{2}}{n_{1}+n_{2}-2}
$$

dimana :

$\bar{x}_{1}=$ Nilai rata-rata postest kelas eksperimen

$\bar{x}_{2} \quad=$ Nilai rata-rata postest kelas kontrol

$n_{1} \quad=$ Banyaknya subyek kelas eksperimen

${ }^{50}$ Riduwan, dan H. Sunarto. 2011. Pengantar Statistika. Bandung : Alfabeta. Hlm.68.

${ }^{51}$ Riduwan, 2007. Belajar Mudah Penelitian untuk Guru-Karyawan dan Peneliti Pemula, Jakarta: Alfabeta, hlm. 124

${ }^{52}$ Ibid., hlm. 120

${ }^{53}$ Sudjana. 2005. Metode Statistika. Bandung: Tarsito. hlm. 239. 
$n_{2} \quad$ = Banyaknya subyek kelas kontrol

$S_{1} \quad$ = Simpangan baku kelas eksperimen

$S_{2} \quad=$ Simpangan baku kelas kontrol

$S^{2} \quad=$ Varians gabungan

Hipotesis statistik yang dirumuskan dalam penelitian ini adalah sebagaiberikut:

Ho: $\mu_{1}=\mu_{2}$ Tidak terdapat pengaruh yang signifikan dari Model Pembelajaran Cooperatif Meaningful Instructional Design (C-MID) terhadap hasil belajar siswa di MTSn Langsa

Ha: $\mu_{1} \neq \mu_{2}$ Terdapat pengaruh yang signifikan dari Model Pembelajaran Cooperatif Meaningful Instructional Design (C-MID) terhadap hasil belajar siswa di MTsN Langsa

\section{HASIL PENELITIAN DAN PEMBAHASAN}

\section{A. Hasil Penelitian}

Penelitian ini dilakukan untuk mengetahui ada tidaknya pengaruh Pengaruh Cooperatif Meaningful Instructional Design (C-MID) Terhadap hasil belajar siswa di MTsN Langsa yang terdiri dari 25 orang siswa kelas eksperimen dan 25 siswa orang kelas kontrol. Data tersebut diperoleh dan dianalisis sehingga dapat memudahkan peneliti untuk mengambil kesimpulan. Hasil penelitian tersebut diuraikan secara mendalam berikut ini :

\section{Data Hasil Pretest}

\section{a. Analisis Deskriptif Data Pretest}

Untuk mengetahui kemampuan awal kelas eksperimen dan kelas kontrol, maka pada masing-masing kelas diberikan pretest. Berdasarkan hasil perhitungan pada lampiran 9 dan 10, diperoleh data hasil pretest yang selengkapnya disajikan pada tabel 4.1. berikut:

\begin{tabular}{|c|c|c|c|c|c|}
\hline \multicolumn{7}{|c|}{ Tabel 4.1 Deskripsi Data Hasil Pretest } \\
\hline Pretest & N & Mean & $\begin{array}{c}\text { Std. } \\
\text { Deviation }\end{array}$ & Minimum & Maximum \\
\hline Eksperimen & 25 & 59,98 & 10,09 & 45 & 80 \\
\hline
\end{tabular}

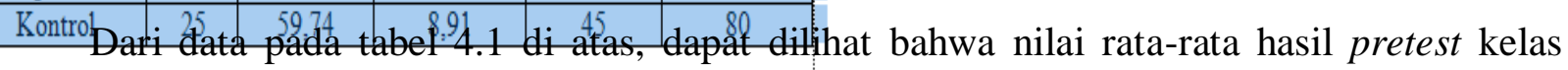
eksperimen dan kelas kontrol hampir sama. Selanjutnya jika dilihat dari nilai standar deviasi, dapat diketahui bahwa nilai standar deviasi kelas eksperimen lebih besar daripada kelas kontrol. Hlm ini menunjukkan bahwa penyebaran data di sekitar rata-rata kelas eksperimen relatif lebih besar dibandingkan kelas kontrol.

\section{b. Analisis Statistik Data Pretest}


Untuk mengetahui apakah data pretest kelas eksperimen dan kelas kontrol memiliki kemampuan awal siswa yang sama atau tidak secara signifikan pada materi segitiga, maka hlm tersebut dapat diperiksa secara statistik dengan uji homogenitas data.

Selanjutnya, kriteria pengambilan keputusan untuk pengujian homogenitas adalah jika $\mathrm{F}_{\text {hitung }}<\mathrm{F}_{\text {tabel }}$, maka Ho diterima, dan jika $\mathrm{F}_{\text {hitung }}>\mathrm{F}_{\text {tabel }}$, maka Ho ditolak. Dari hasil perhitungan pada lampiran 11 , berikut ini ditampilkan tabel hasil uji homogenitas data pretest :

Tabel 4.2 Hasil Uji Homogenitas Data Pretest

\begin{tabular}{|l|c|c|c|c|}
\hline \multirow{2}{*}{ Kelas } & \multirow{2}{*}{$s^{2}$} & \multicolumn{2}{|c|}{ Dk } & \multirow{2}{*}{ Fune } \\
\cline { 5 - 6 } & & Pembilang & Penyebut & \\
\hline Ekperimen & 101,76 & 24 & 24 & 1,28 \\
\hline Kontrol & 79,44 & & & \\
\hline
\end{tabular}

Berdasarkan tabel 4.2 di atas menunjukkan bahwa pada taraf signifikansi $5 \%$ diperoleh $\mathrm{F}_{\text {hitung }}=1,28$ dan $\mathrm{F}_{\text {tabel }}=1,98$; karena $\mathrm{F}_{\text {hitung }}<\mathrm{F}_{\text {tabel }}$ hlm ini berarti bahwa Ho diterima, yaitu varians data pretest kelas eksperimen dan kelas kontrol adalah homogen.

\section{Data Hasil Postest}

\section{a. Analisis Data Postest}

Data hasil postest pada penelitian ini adalah data hasil belajar siswa pada materi segitiga setelah diberikannya perlakuan yang berbeda pada kelas eksperimen dan kelas kontrol. Data hasil postest selengkapnya disajikan pada tabel berikut :

Tabel 4.3 Deskripsi Data Nilai Postest

\begin{tabular}{|c|c|c|c|c|c|}
\hline \hline Posttest & N & Mean & $\begin{array}{c}\text { Standar } \\
\text { Deviasi }\end{array}$ & Minimum & Maximum \\
\hline Ekspenimen & 25 & 78,02 & 13,68 & 55 & 100 \\
\hline Kontrol & 25 & 69,80 & 11,07 & 50 & 95 \\
\hline
\end{tabular}

Dari data pada tabel 4.3 diatas memperlihatkan bahwa kelas eksperimen memperoleh nilai maksimum 100, minimum 55 dan nilai rata-ratanya adlaah 78,02. Sedangkan kelas kontrol memperoleh nilai maksimum 95, minimum 50 dan nilai rata-ratanya adalah 69,80. Selanjutnya, dilihat dari nilai standar deviasi data postest, kelas eksperimen memperoleh 13,68 sedangkan kelas kontrol memperoleh 11,07. Berdasarkan deskripsi data tersebut, Hlm ini menunjukkan bahwa penyebaran data disekitar ratarata kelas eksperimen dan kelas kontrol relatif sama, dapat dilihat bahwa ternyata ada perbedaan pada kelas kontrol dan kelas eksperimen, akan tetapi untuk melihat apakah perbedaan tersebut signifikan atau tidak, maka akan digunakan uji statistik sebagai berikut :

\section{b. Analisis Statistik Data Postest}

Untuk mengetahui apakah data postest kelas eksperimen dan kelas kontrol berasal dari populasi yang berdistribusi normal atau tidak, dan untuk mengetahui apakah hasil belajar siswa 
pada materi segitiga sama atau tidak secara signifikan, maka hlm tersebut dapat diperiksa secara statistik dengan langkah-langkah sebagai berikut:

\section{Uji Normalitas Data Postest}

Nilai postest kelas eksperimen dan kelas kontrol dalam penelitian ini juga akan diuji normalitasnya menggunakan menggunakan uji Chi-Kuadrat dengan taraf signifikansi $5 \%$. Kriteria pengujian tolak $\mathrm{H}_{\mathrm{o}}$ jika $\chi^{2} \geq \chi_{(1-\alpha)(k-1)}^{2}$ dengan $\alpha=0,05$. Dalam hlm lainnya, $\mathrm{H}_{\mathrm{o}}$ diterima.

Berdasarkah hasil perhitungan pada lampiran 16, berikut ini merupakan hasil perhitungan uji normalitas data postest pada kelas eksperimen dan kelas kontrol pada tabel 4.4:

Tabel 4.4 Hasil Uji Normalitas Data Postest

\begin{tabular}{|l|c|c|c|c|}
\hline \multicolumn{1}{|c|}{ Analisis } & N & $\boldsymbol{x}^{2}$ time & $\boldsymbol{x}^{3}$ bid & Keterangan \\
\hline Eksperimen & 25 & 5,42 & 7,81 & Data berdistribusi nomal \\
\hline Kontrol & 43 & 2,26 & 7,81 & Data berdistribusi normal \\
\hline
\end{tabular}

Dari tabel 4.4 di atas, dapat dilihat bahwa untuk data posttest kelas eksperimen dan kelas

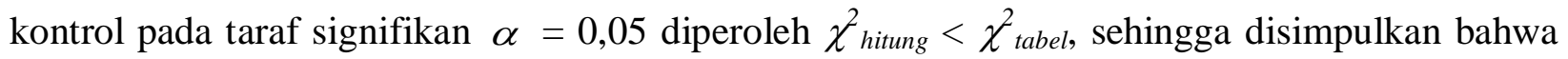
nilai postest kelas kontrol dan kelas eksperimen berdistribusi normal, ini menunjukkan bahwa uji persyaratan dapat dilanjutkan.

\section{Uji Homogenitas Data Postest}

Pengujian ini dilakukan untuk melihat kesamaan varians antara dua kelas eksperimen dan kelas kontrol. Berikut ini ditampilkan tabel hasil pengujian homogenitas:

\section{Tabel 4.5 Rekapitulasi Hasil Perhitungan Uji Homogenitas}

\begin{tabular}{|l|c|c|c|c|}
\hline \multirow{2}{*}{ Kelas } & \multirow{2}{*}{$s^{2}$} & \multicolumn{2}{c|}{ Dk } & \multirow{2}{*}{ F } \\
\cline { 3 - 4 } & & Pembilang & Penyebut & \\
\hline Ekpenimen & 187,09 & 24 & 24 & 1,53 \\
\hline Kontrol & 122,50 & & & \\
\hline
\end{tabular}

Berdasarkan tabel di atas menunjukkan bahwa pada taraf signifikan $\alpha=0,05$ diperoleh $\mathrm{F}_{\text {hitung }}=1,53$ dan $\mathrm{F}_{\text {tabel }}=1,98$, karena $\mathrm{F}_{\text {hitung }}<\mathrm{F}_{\text {tabel }}$ yaitu $1,53<1,98$, hlm ini membuktikan bahwa varians kelas eksperimen dan kelas kontrol adalah sama (Ho diterima); sehingga sampel yang digunakan juga dapat mewakili populasi yang ada.

\section{c. Uji Hipotesis}

Untuk mengetahui ada tidaknya Pengaruh Cooperatif Meaningful Instructional Design (C-MID) Terhadap hasil belajar siswa di MTsN Langsa, maka dilakukan uji hipotesis dengan menggunakan rumus uji t. Hasil pengujian hipotesis dapat dilihat pada tabel di bawah ini: 
Tabel 4.6 Rekapitulasi Hasil Perhitungan Uji hipotesis

\begin{tabular}{|c|c|c|c|c|c|c|}
\hline \multirow{2}{*}{ Kelas } & \multirow[t]{2}{*}{-} & \multirow{2}{*}{$s^{2}$} & \multirow{2}{*}{ spab } & \multicolumn{2}{|c|}{ Nhit } & \multirow{2}{*}{ Kesimpulan } \\
\hline & & & & thing & talal & \\
\hline Ekspeimen & 78,02 & 187,09 & \multirow{2}{*}{12,44} & \multirow{2}{*}{2,36} & \multirow{2}{*}{1,67} & \multirow{2}{*}{$\begin{array}{l}\text { Ho ditolak dan } \\
\text { Ha diterima }\end{array}$} \\
\hline Kontrol & 69,80 & 122,50 & & & & \\
\hline
\end{tabular}

Hasil pengujian hipotesis dapat dilihat pada lampiran 18 dengan taraf signifikan $\alpha=$ 0,05 diperoleh $t_{\text {hitung }}=2,36$ dan $t_{\text {tabel }}=1,67$, dan ini berarti $t_{\text {hitung }} \geq t_{\text {tabel }}$; sehingga dapat disimpulkan bahwa Ho ditolak dan Ha diterima; yaitu ada Pengaruh Cooperatif Meaningful Instructional Design (C-MID) Terhadap hasil belajar siswa di MTsN Langsa

\section{B. PEMBAHASAN}

Berdasarkan hasil analisis nilai postest yang diperoleh setelah dilakukan pembelajaran, terlihat bahwa Pengaruh Cooperatif Meaningful Instructional Design (C-MID) Terhadap hasil belajar siswa di MTsN Langsa. Hlm ini membuktikan bahwa pemilihan model pembelajaran yang sesuai sangatlah berpengaruh terhadap prestasi belajar siswa.

Pemilihan model pembelajaran merupakan langkah awal keberhasilan pembelajaran karena dapat meningkatkan hasil belajar siswa agar lebih tanggap menghadapi permasalahan yang menyangkut tentang matematika. Salah satunya adalah Cooperatif Meaningful Instructional Design (C-MID). Model pembelajaran Cooperatif Meaningful Instructional Design (C-MID) menganggap bahwa suatu pembelajaran akan efektif jika memperhatikan tiga hlm, yaitu Auditory, Intellectual dan Repetition. Auditory berarti indra telinga digunakan dalam belajar dengan cara menyimak, berbicara, presentasi, argumentasi, mengemukakan pendapat, dan menanggapi. Intellectual berarti kemampuan berpikir perlu dilatih melalui latihan bernalar, mencipta, memecahkan masalah, mengkonstruksi, dan menerapkan. Repetition berarti pengulangan diperlukan dalam pembelajaran agar pemahaman lebih mendalam dan lebih luas, siswa perlu dilatih melalui pengerjaan soal, pemberian tugas dan kuis.

Dengan demikian dapat disimpulkan bahwa pembelajaran dengan menggunakan model Cooperatif Meaningful Instructional Design (C-MID) dapat meningkatkan hasil belajar siswa khususnya dalam pelajaran matematika. Karena model ini siswa dibiasakan untuk menggunakan indera telinga dan kemampuan berpikirnya untuk melakukan pemecahan masalah sehingga siswa diharapkan memiliki kemampuan untuk menyelesaikan masalah-masalah yang berkaitan dengan kehidupan sehari-hari yang diformulasikan ke dalam bentuk matematika serta mampu merepresentasikan hasil pemecahan masalahnya tersebut.

\section{KESIMPULAN}

Berdasarkan hasil penelitian diperoleh $\mathrm{t}_{\text {hitung }}=2,36$ dan $\mathrm{t}_{\text {tabel }}=1,67$, dan ini berarti $\mathrm{t}_{\text {hitung }}$ $\geq \mathrm{t}_{\text {tabel }}$, sehingga dapat diambil kesimpulan bahwa ada pengaruh Cooperatif Meaningful Instructional Design (C-MID) Terhadap hasil belajar siswa di MTsN Langsa. Penggunaan model 
pembelajaran model pembelajaran Cooperatif Meaningful Instructional Design $(C$ - MID) terbukti dapat meningkatkan hasil belajar peserta didik dibandingkan tanpa menggunakan model pembelajaran Cooperatif Meaningful Instructional Design (C-MID) pada materi segitiga

\section{SARAN-SARAN}

Berdasarkan hasil penelitian yang telah disimpulkan, maka dalam upaya meningkatkan mutu pendidikan perlu dikemukakan beberapa saran berikut:

1. Guru dapat menggunakan model pembelajaran Cooperatif Meaningful Instructional Design (C-MID) sebagai salah satu alternatif model pembelajaran matematika.

2. Untuk penelitian lebih lanjut dapat menggunakan model pembelajaran Cooperatif Meaningful Instructional Design (C-MID) dengan mengkombinasikan model pembelajaran lain, sehingga dapat berpengaruh pada hasil belajar siswa khusunya pada bidang studi matematika

\section{DAFTAR PUSTAKA}

Agus,Suprijono. 2011. Cooperative Learning, Teori dan Aplikasi PAIKEM, Yogyakarta: PustakaPelajar,

Anita Lie, 2004 Cooperative Learning, Mempraktekkan Cooperative Learning di Ruang-Ruang Kelas, (Jakarta: Grasindo Gramedia Widiasarana Indonesia.

Arikunto, Suharsimi. 2009. Dasar-dasar Evaluasi Penelitian, Jakarta: Bumi Aksara

Asep Jihad \& Abdul Haris. 2008. Evaluasi Pembelajaran. Yogyakarta: multi pressindo.

Budiningsih, Asri C. 2005. Belajar dan Pembelajaran. Jakarta: PT. Rineka Cipta

Dimyati dan Mudjiono. 2006. Belajar dan Pembelajaran. Jakarta: PT. Asdi Mahasatya

Djamarah S. B. Pendekatan dan Metode Pembelajaran. http:// Smacepiring. Wordpress. Com / 2008 / 02 / 19 / Pendekatan dan Metode Pembelajaran /, 5 September 2016

Evalina \& Hartini. 2010. Teori Belajar dan Pembelajaran. Bogor : Ghlmia Indonesia.

Husna. Peningkatan hasil belajar Matematis Siswa Sekolah Menengah Pertama Melalui Model Pembelajaram Kooperatif ( Banda Aceh .2013. 2013.Jurnal Vol 1 No 2 Tahun 2014)

Isjoni, 2009. Pembelajaran Kooperatif: Meningkatkan Kecerdasan Komunikasi Antar Peserta Didik, Yogyakarta: Pustaka Pelajar,

Kunandar 2008. Guru Profesional, Impementasi Kurikulum Tingkat Satuan Pendidikan (KTSP) dan Sukses dalam Sertifikasi Guru. Jakarta: PT. Raja Grafindo Persada,

Made Wena, 2009. Strategi Pembelajaran Inovatif Kontemporer, (Jakarta: Bumi Aksara)

Made, Desak. Ada pengaruh penerapan model pembelajaran MID berbantuan Media teka teki silang dan motivasi berprestasi terhadap hasil belajar IPS siswa kelas V SD Gugus Untung Surapati (Denpasar Timur.2014. Jurnal Vol 2 No: 1 tahun 2014)

Masruhan. (Meningkatkan Hasil Belajar Matematika Pada Pokok Bahasan Operasi Hitung Bentuk Aljabar Melalui Model pembelajaran MID Pada Siswa Kelas VII-A Mts 
Islamiyah Sumpiuh - Banyumas Tahun Pelajaran 2006/2007.Jurnal tahun 2007 diakses 10 Mei 2017

Ngalimun. 2014. Strategi dan Model pembelajara. Yogyakarta :CV Aswijaya.

Paimin, joule Ekaningsih. 1998. Agar Anak Pintar Matematika. (Jakarta: Puspa Swara,

Richard I. Arends, 2008. Learning To Teach, ed.VII. buku 2, (Yogyakarta: Pustaka Belajar,

Riduwan, 2007. Belajar Mudah Penelitian untuk Guru-Karyawan dan Peneliti Pemula, Jakarta: Alfabeta

Riduwan, dan H. Sunarto. 2011. Pengantar Statistika. Bandung : Alfabeta.

Riyanto, Yatim. 2010. Paradigma Baru Pembelajaran. (Jakarta: PT. Kencana Prenada Media Group,

Rusman, 2010. Model-Model Pembelajaran, Jakarta: PT. Raja Grafindo Persada,

Russefendi, 1994. Dasar-dasar Penelitian Pendidikan dan Bidang Non-Eksata Lainnya, (Semarang: IKIP.

Sudjana. 2005. Metode Statistika. Bandung: Tarsito.

Suharsimi ,Arikunto. 2005. Dasar-dasar Evaluasi Pendidikan. Jakarta: Bumi Aksara.

Suherman, E. 2003. Evaluasi Pembelajaran Matematika. Bandung: JICA UPI.

The Third International Mathematics and Science Study (TIMSS).2008. 